\title{
Group compositions: the politics of technology implemented in smallholder farming
}

\author{
Harro Maat ${ }^{1}$ \\ Wageningen University, the Netherlands
}

\begin{abstract}
This article investigates the connection between performance, group, and society. The argument is that group formation around particular farm operations and the details of the activities they engage in are an expression of the preferred way of technology implementation. The argument is developed using Paul Richards' notion of agriculture as performance. Two cases are presented. The first is the composition of a spraying team for weed control in smallholder oil palm production in Sumatra, connected to a global agreement on sustainable oil palm production, known as the Roundtable on Sustainable Palm Oil (RSPO). The second case is about a team of women transplanting young rice seedlings on prepared paddy fields in a village in Uttarakhand, India. A new way of rice transplanting was introduced by a local nongovernmental organization, known as the System of Rice Intensification (SRI). The analysis shows that group performances provide essential information about how introduced plans, regulations and material designs are reworked and turned into meaningful and effective changes to agricultural practices. The article concludes that these activities are not merely technical adjustments but in themselves express arguments about the preferred way of organising farming, farm labor, and payments. Performing groups thus exert a form of bargaining power against development actors.
\end{abstract}

Keywords: Group performance, smallholder farming, technology transfer, political acts

\section{Résumé}

Cet article examine le lien entre la performance, le groupe et la société. L'argument est que la formation de groupes autour d'exploitations agricoles particulières et le détail des activités dans lesquelles ils se lancent sont l'expression du moyen privilégié de mise en œuvre de la technologie. L'argument est développé en utilisant la notion de Paul Richards de l'agriculture en tant que performance. Deux cas sont présentés. Le premier est la composition d'une équipe de pulvérisation pour la lutte contre les mauvaises herbes dans la production de palmier à huile à Sumatra, liée à un accord mondial sur la production durable de palmier à huile, connu sous le nom de Roundtable on Sustainable Palm Oil (RSPO). Le deuxième cas concerne une équipe de femmes transplantant de jeunes plants de riz dans des rizières préparées dans un village d'Uttarakhand, en Inde. Une nouvelle méthode de repiquage du riz a été introduite par une organisation non gouvernementale locale, connue sous le nom de Système d'intensification du riz (SRI). L'analyse montre que les performances de groupe fournissent des informations essentielles sur la façon dont les plans, les réglementations et les conceptions des matériaux sont retravaillés et transformés en changements significatifs et efficaces des pratiques agricoles. L'article conclut que ces activités ne sont pas simplement des ajustements techniques, mais expriment en elles-mêmes des arguments sur la manière préférée d'organiser l'agriculture, le travail agricole et les paiements. Les praticiens exercent donc une forme de pouvoir de négociation contre les acteurs du développement.

Mots-clés: performance du groupe, petites exploitations agricoles, transfert de technologie, actes politiques

\footnotetext{
${ }^{1}$ Dr. Harro Maat, Associate Professor, Knowledge Technology and Innovation group, Department of Social Sciences, Wageningen University, the Netherlands. Email: harro.maat "at" wur.nl. Thankyou to Special Section editor Andrew Flachs and referees. This is the fourth article in Andrew Flachs (ed.). 2018. "Performing development roles: theorizing agriculture as performance", Special Section of the Journal of Political Ecology 25: 638-764.
} 


\section{Resumen}

La noción de "agricultura como performance" captura la improvisación en el éxito de las operaciones agrícolas. Por tanto, el argumento del performance hace hincapié en las particularidades de la improvisación y habilidades dirigidas a las operaciones agrícolas. El papel de la interacción social y formación de grupos es esencial para la expresión y empleo de las habilidades de improvisación. Este artículo investiga las conexiones que hay entre performance, grupos y sociedad. Se desarrolla un marco conceptual de los rasgos esenciales de los grupos performativos: la coordinación de actividades, las particularidades de la situación en que las actividades se realizan, así como el proceso de aprendizaje. Como ejemplo, dos casos se analizan bajo este marco. El enfoque es en cómo las recién introducidas descripciones del trabajo resultan en un grupo performativo particular. El primer trabajo de grupo presentado es un equipo de aspersión para el control de maleza en una pequeña productora de aceite de palma, conectada al mismo tiempo a un acuerdo global de producción sustentable de aceite de palma, conocido como Mesa Redonda de Aceite de Palma Sustentable (RSPO). El segundo caso es sobre un equipo de mujeres que trasplantan plantas de semillero de arroz en arrozales preparados en la villa de Uttarakhand, en India. Un nuevo método de trasplante de arroz fue introducido por una organización local no gubernamental, conocida como Sistema de Intensificación del Cultivo del Arroz (SRI). El análisis muestra que los performances de grupo proveen una información esencial sobre cómo planes, regulaciones y diseño de materiales que son introducidos, son reformulados y convertidos en prácticas agrícolas que resultan tanto significativas como efectivas.

Palabras clave: Actuación grupal, pequeños agricultores, transferencia de tecnología, actos políticos

\section{Introduction}

This article addresses the crucial role of group activity in agriculture. Stressing the importance of collectives and groups in agriculture seems to state the obvious. Rural sociologists focus on farm communities, the farm household is a key unit of analysis for agricultural economists, and in agricultural extension group-based transfer of knowledge is the norm. The social formations commonly used in sociology and economics are co-produced by the underlying theories and typically based on statistical aggregates (Douglas and Ney 1998; Latour 2005; Porter 1995). Policies and projects for rural development work with the same categories as the basis for interventions. Agricultural extension strategies, for example, typically work with groups for the convenience of information dissemination (Isubikalu 2007). Underlying this is a behavioural model of individual decision-making based on information processing (Hoffmann, 2007). An alternative understanding of groups, rooted in social anthropology, is the emergence of collective values and shared beliefs through joint activity in a specific situation (Collins 2004). The argument developed here is that group formation and group confirmation through shared activities is an important addition to existing notions of collective action in rural development and the powers at play in agricultural change.

Agriculture comprises of a variety of activities that are enhanced by collective action. The way farm operations establish the collective is a key component of a performative understanding of agriculture. The concept of agriculture as a performance is comes from Paul Richards $(1989,1993)$, who emphasizes the improvisational character of agricultural work. Rural development planners and designers of agricultural technologies, Richards argues, assume that engaging in an activity is about the application of preconceived plans, existing in the mind as memorized rules and abstract schemata. Instead, farm operations evolve as a response to the specific conditions at hand. The 'knowledge', i.e. the capacity of a farmer, is better understood as embodied experience, expressed in skilful acts. The performance argument thus stresses the improvisational and skill-based character of farm operations. Richards used the analogy of a musical performance to emphasize that farmers, like musicians, have to respond to a variety of details that come with the particular setting in which the performance takes place. The reference to musical performance helpfully clarifies the way activity is sustained in group interaction.

Playing in a band or orchestra requires the skills to master the instrument as well as the capacity to attune to fellow musicians and respond to the gestures of the conductor. Musicians also interact with the stage and scenery in which they perform, including anticipating and reacting to the audience. These interactions together result in what Tim Ingold (1993: 160) called "the achievement of resonance." A 
performance, more generally understood as a shared operational practice, constitutes the collective. Ingold (ibid.) contends that "in the resonance of movement and feeling stemming from people's mutually attentive engagement, in shared contexts of practical activity, lies the very foundation of sociality." In his writings about the civil war and post-war reconstruction in Sierra Leone, Richards showed how ritual performances are interwoven with strategic goals and practical achievements, empowering collective action (e.g. Richards 2005; 2007).

The interconnectedness between group and activity is taken up here to get a better understanding of how groups of farm workers respond to new instructions and material implements based on policies and technological designs. Moreover, the way performing groups adjust to and 'enact' introduced innovations within a specific context creates a 'technopolitical sphere' (Winner 1995) where performing groups state their claims. In other words, more than merely adjustments and alterations of the provided instructions, a performing group is 'technical democracy in action' (Callon, Lascoumbes and Barthes 2001). The outcomes of group performances provide important lessons for policy makers and researchers about the feasibility and overall impact of proposed plans in designed innovations.

After elaborating on the technopolitics of group performance, the article presents two cases of groups reworking introduced innovations. The first case is about a group of workers in a cooperative smallholder oil palm scheme in Sumatra, Indonesia and in the second case involves following a team of rice farmers in Uttarakhand, India. These two cases are presented to show some of the common patterns emerging in group performances in different environments and in response to very different kinds of introduced changes to these practices. The specific tasks presented here, as performed by the two different groups, are both part of a wider set of tasks, fully presented and analysed in the two mentioned thesis reports.

\section{The social and technical interaction of performing groups}

The success of a musical performance is generally measured by the applause received from the audience. An audience to a musical band is hardly ever a random collection of people who managed to get a ticket. For professional bands and orchestras, the concert hall will be predominantly filled by fans, who may know the performing musicians quite well. Amateur bands, orchestras or choirs active in local communities typically have an audience dominated by family and friends. In both cases, however, the connections and relationships represent a social network out of which the performing group is composed. In other words, the connection between performing musicians and audience is how performers relate to wider society (Flachs and Richards 2018). Although all sorts of communication between performers and audiences are possible, the essence of the relationship is the performance itself. The performance, therefore, is essential for both the interaction between members of a performing group and the interaction between performing group and wider society. Projected on rural development and technology introduction in agricultural settings, this requires an analytical focus on the coordination of activities, the situation in which activities take place, and the change process attached to activities.

Performing groups emerge through shared activity (Collins 2004; Harrington and Fine 2006). The relationship between activity and group is reciprocal. Bands, teams, and task forces are effective in getting things done and, vice versa, affinity between group members is established through common achievements. An important component of group formation is symbolic activity, establishing and confirming social bonds in a predominantly normative way. This is the domain of ritual action central in the work of Durkheim (1995 [1912]) and Collins (2004). There is a thin line between rituals and the more practical goals of collective action. Both instrumental and ritual group activities confirm group affinity. Group affinity is perhaps less prominent in social theory, but equally crucial. Purposively achieving certain tasks in a particular environment creates mutual commitment and therewith establishes group identity (Harrington and Fine 2006; McFeat 1974). In agrarian settings, many farm operations that require collective action start or end with ritual acts (Lansing 1985; Sen et al. 2017). More generally, all forms of agriculture, including 'high-tech' industrial farming, contain elements of ritual initiation and confirmation (Richards 2004). 
Individuals need coordination to move around in a specific situation, which may appear to be merely a physiological coordination between sensory perception, the brain, and muscles. However, these basic human skills are inherently social. The techniques of the body, as Marcel Mauss called them, acquire meaning and thereby a distinct cultural character through social interaction (Schlanger 2006). The social significance of 'individual' activities that require basic bodily skills often escapes our attention. The same applies to tasks that involve interactions with material objects and simple tools (Dant 2007). Most tasks are part of a wider set of tasks. The significance of coordination and shared meaning becomes more apparent when looking at task sets, mostly performed by several people. Sequential tasks form an operational chain (Lemonnier 1992) and sets of sequential and parallel tasks are what Tim Ingold (1993) calls a taskscape. Effective manoeuvring in a taskscape or successful progression through an operational chain is what characterises a successful group. Vice versa, groups increase in coherence and status when task ordering and task coordination lead to desired outcomes (McFeat 1974; Sigaut 2002). These insights provide a useful socio-technical definition of farming. Depending on what crops are grown and what animals are reared, a farm is a taskscape in which the bio-rhythms of crops and livestock set the beginning and end of specific operational chains.

The task performance of a group or individual is always connected to a specific setting or task environment. The task environment facilitates performances in interaction. The notion of affordances (Gibson, 1979) captures the process in which a (natural) environment changes in functionality and value, depending on which humans (Gibson writes about organisms more generally) engage with the environment. What may appear as merely a tract of forest becomes a variety of different forest-like spaces through the way it is used and perceived by various groups of citizens (Macnaghten and Urry 2000). Such different users and uses may coexist peacefully but may also be a cause for conflict. Todd Crane (2010) describes how two groups of agropastoralists in Mali try to avoid conflicts over farmland and pastures in the same geographical space. Because the two groups have different social and cultural traditions, they hold different values about the ecologies and how to operate effectively in what appears to be a two-in-one socioecological space. The notion of affordances is equally helpful to understand the way tools, machines, and other human-made objects are put to use in a task environment. For specific objects introduced from elsewhere, in a process generally referred to as technology transfer, affordances indicate a connection between user-environments and the work of designers and planners (Glover et al. 2017; Pfaffenberger 1992). Designers and planners have the task, working in environments known as studios, laboratories, and research institutes, to project a particular (future) interaction between objects and user groups into particular user settings. Such plans (Suchman 1987) or scripts (Latour 1992) can change the affordances in a variety of user settings but never predefine how they play out.

Agricultural development projects, connecting the user environments of rural communities with the design environments of designers and planners, imply a process of social interaction and technical change. As new affordances appear, user groups engage in a process of learning and reskilling to achieve the set goals. Groups are typically effective in learning because communication, response, and feedback between members is conducive to processing information (McFeat 1974). Projects introducing new technical inputs and proposing new farming methods create space for group learning processes through a variety of means, such as farmer field schools and learning alliances (Flor et al. 2016; Isubikalu 2007). Development agencies, public or private, feed the group learning process with new information. Such information is never merely technical or otherwise impartial but based on particular ambitions and interests (Stone 2016). When different agencies provide information with diverse or even contradictory ambitions and interests, this may lead to disruption and even de-skilling (Stone 2007, 2010). However, performing groups have the capacity to oppose the changes proposed by development agencies through reconfiguration (Glover et al. 2017). In line with Richards' argument for performative participation (2007), such reconfigurations should be seen as an expression of community values. The performance is the means by which groups employ their power to change the course of action. The characteristics and potential of performing groups are an important but understudied phenomenon in rural development. At the end of the article possible reasons for this neglect are discussed. In what follows two examples are provided of group performance in different contexts. 


\section{Methods}

Technography is an obvious and adequate approach to study technology used by groups. The focus of technography is on the interaction between humans and tools within a particular setting (Richards 2004; Sigaut 2002). The essence of technography is empirical observation. Taking photographs and video filming are helpful tools alongside interviews (Gore et al. 2002). Technography was used in both studies presented here. The methodological design was set up around key farming activities. The author was involved in the study design, analysis, and writing of both case studies. The actual data collection in the field was by Lisnawati for the oil palm case and for the rice case by Debashish Sen. The first case is taken from a study among smallholder oil palm farmers in Sumatra, Indonesia. A project lead by an international team of experts introduced improved practices for fertiliser application, weed management, pruning, and harvesting. The oil palm farmers were all members of a cooperative, coordinating the introduction of the improved practices. What is presented here are the results from observing a team of workers recruited for weeding. These workers formed a spraying team that was supposed to work with new guidelines for spraying herbicides, the common weeding practice. An elaborate version of the results, including a study of a team of harvesters, is presented in Lisnawati's Master's thesis (2017).

The second example is a case study from a group of farm workers transplanting rice. Here too, improved practices were introduced by a local non-governmental organization (NGO). The NGO was backed by an international network of organizations promoting the System of Rice Intensification (SRI). The introduced SRI practices comprised the way seedlings were grown and transplanted, water management, weeding and fertiliser application. Results presented here are about the transplanting activities, observed over two subsequent seasons in a village in Uttarakhand, India. The presented material was part of a larger study on the implementation of the SRI practices in three different villages in Uttarakhand (Sen 2016). The Indian workers transplanting the rice seedlings and the Indonesian workers spraying oil palm fields were all women. The gendered nature of the work is likely an important element of the group dynamics that evolved, but this was not a specific focus of the studies.

\section{Spraying teams for sustainable oil palm production}

The first task group presented is a spraying team for weed control in smallholder oil palm production. The work of the team was linked to a global debate on oil palm and sustainable production through an agreement between multinational companies, international NGOs and a large number of national organizations and companies, known as the Roundtable on Sustainable Palm Oil (RSPO). The organization stemming from the agreement has its headquarters in Switzerland and offices in Malaysia and Indonesia, the world's largest producers of palm oil. According to the RSPO website, they have certified 19\% of global oil palm production. ${ }^{2}$ The standards are specified, implemented and monitored by local organizations. However, the RSPO organization has limited means to ensure local organizations follow the set standards (Gilbert 2012; Ruysschart and Selles 2014). The focus here is how set standards trickle down to the field level, in particular the way guidelines for herbicide spraying are put to practice in a smallholder oil palm scheme in Sumatra, Indonesia.

The smallholder palm oil schemes on Sumatra are organized through village level cooperatives (Koperasi Unit Desa) united in the Amanah Association, which received the RSPO certification. The guidelines they set for spraying are basic rules for safe application of the toxic chemicals. Part of the rules are about safe storage of the chemicals and equipment, including dealing with empty containers and other waste material. Other rules are about proper spraying, including promoting sprayer safety through wearing protective clothing, minimizing ineffective spraying through assessment of what chemicals are needed in what dosage, and avoiding contamination by staying away from open water and cleaning equipment in designated spots only (Figure 1). To ensure these rules are followed, the cooperatives created specialised spraying 'team units' (Tim Unit Semprot). The activities of one such team, operational in three villages in the Pelalawan District of Riau Province, Sumatra, were followed for two weeks.

\footnotetext{
${ }^{2}$ https://rspo.org/about/impacts, assessed 11 January, 2018.
} 

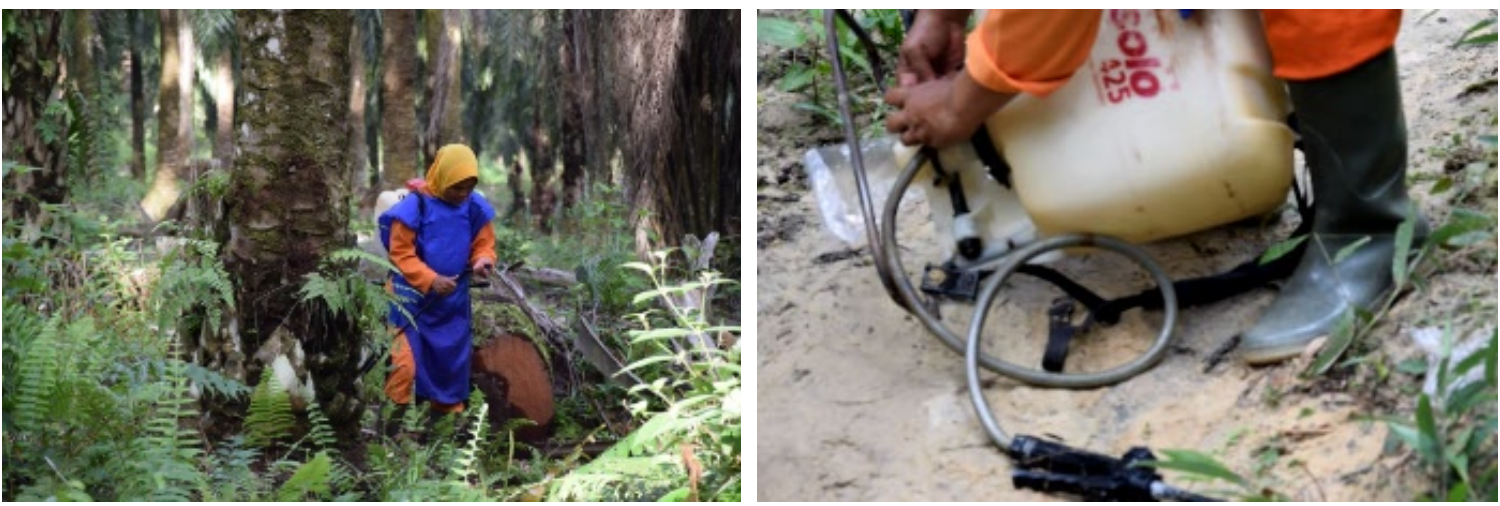

Figure 1: Spraying palm oil in Sumatra.

Each spraying team has a daily target of four kavlings, a unit with variable size but on average about 2 hectares of oil palm. From early morning until noon, each kavling is covered by two sprayers. Each team ideally consists of twelve sprayers, a team leader (mandor), and a driver, although group size varies. The sprayers, all women, have no fixed contracts or regular working schedules. They may have other jobs too, including being hired as sprayers directly by farmers. To reach the daily performance target, at least seven sprayers are needed, along with the mandor and driver. A representative of the cooperative and an administrator who handles the bookkeeping are frequently present, but they not essential to getting the spraying finished. In case only the minimum number of seven sprayers are there, the mandor always consults the women to find out if they want to work. The low number requires an extra effort to cover the four kavlings for which they do not get paid extra.

The driver usually picks up the women around 6.30 in the morning. An early start is preferred so that the team can be finished before lunch. However, late arrival of the car was very common and the women often complained about the 'lazy' driver. The mandor comes with a separate car, bringing the equipment, a tank of water and food. The team has a quick breakfast before starting. The mandor does a round through the fields first, to observe the intensity and types of weeds that are there. According to the instructions, the mandor should do this inspection on the day before the team starts spraying. Given the distances between spraying locations some mandors consider this to be too much hassle. Based on his observations, the mandor decides on the type and dosage of herbicides. There are guidelines and formulas for calculating dosage and volume-to-field ratios. On none of the occasions observed did the mandor use any of these formulae but instead determined dosage and volumes from his direct observation. There were more guidelines that were followed up by improvisation. Cleaning the spraying equipment, for example, should be done at an allocated spot, preventing leakage of chemicals. However, when the sprayers stopped working, mostly caused by debris in the nozzle, the women solved this on the spot. That implied partly dissembling the sprayer, resulting in leakage of the solution and direct contact between the solution and the woman's skin.

Three different chemicals are used: glyphosate, better known as Roundup and locally called racun kuning; triclopyr, which is sold under the trade name Garlon; and paraquat or gramoxone. Roundup is used to control narrow-leaved weeds, Garlon for the more woody and broadleaved plants. A common weed treated with Garlon is anak kayu (Clidemia hirta). Paraquat essentially kills most weeds instantly but is not used by preference. One major reason the spraying teams are created is to apply these very toxic herbicides in a responsible way. One of the instructions was to keep chemicals separate. When different types of weeds are found, which is usually the case, the same field has to be walked through twice, in parallel by two sprayers or sequentially by the same sprayer applying the appropriate chemical to the spots where particular weeds prevail. After several attempts to make this work, the mandor and agricultural advisor from the 
cooperative considered this too complicated and decided to work with mixtures of different chemicals, mostly Roundup and Garlon. Adding herbicide to the water-filled spraying containers, carried by the women like a backpack, is supposed to be done by the mandor. The water is taken for the tank on the car and the driver assists in this. Most of the time sprayers filled their own container, especially when refilling after their first round. When fields stretched out far, they took a flagon of herbicide and an empty bucket which they filled from a nearby stream or drain to refill their spray container. As they were pressed to get the work done, the amount of herbicides poured into the container was usually not measured carefully.

The sprayers have their names written on their spraying container. The first to get her container filled is expected to walk to the farthest lane and to start spraying. The others follow suit, each taking the next lane between the palm trees. In principle, there is a fixed schedule allocating sprayers to lanes but because the number of sprayers fluctuates, the schedule has to be improvised each day. Moreover, the sprayers often end up with an empty container before they reach the end of their path. The mandor explained that, as rule of thumb, a full container of 15 litres should be enough for 14-16 trees when weeds are dense and 18-20 trees for less weedy parts. Originally the marking of the beginning and endpoints was done with coloured cloths. A sprayer puts a blue cloth on the ground to flag where she began, yellow to flag where she stopped halfway, and red at the end of a finished lane. When the field was fully completed the mandor went to collect the cloths before moving to the next field. However, in most cases some sprayers are finished and move on to the next field while others are still spraying the first field. The mandor is then very busy organising the movements between fields. Collecting the cloths delayed the process and they stopped using them. Instead, when a sprayer finishes her container, she uproots a weed or breaks a fresh palm leaf to mark where she stopped.

The smallholders own one or two kavlings, so a spraying team serves several farmers each day. How much a farmer pays depends on the amount of herbicides used and the number of sprayers. Payment is done either directly or through the cooperative. Farmers are free to use the service of the spraying team. Some smallholders hire-in sprayers who also work for the cooperative teams. Others have the spraying done by the same people helping in other jobs, such as fertiliser application and harvesting. For the farmer, hiring one or two sprayers directly is cheaper than the price they pay to the cooperatives' spraying teams, paying fewer workers at a higher hourly rate. For the same reason, women prefer to be hired as sprayers directly, which is the reason why the spraying teams are often smaller than the preferred size.

\section{Transplanting rice under SRI}

The second case is about a team of women in Phalenda, a village in Uttarakhand, India. Their set task was to transplant young rice seedlings on prepared paddy fields (Figure 2). A central component of this new rice cultivation method, known as the System of Rice Intensification (SRI), was to increase the space between rice plants. The SRI principles were first compiled in in the 1980s by Fr. Henri de Laulanié, a Jesuit priest who was trained in agronomy and worked in Madgascar (Glover 2011). SRI received international attention after publications by Norman Uphoff $(1999,2003)$ and Willem Stoop (Stoop et al. 2002), who portrayed SRI as a scientific breakthrough in agronomy. Although rice scientists contested these claims, SRI was taken up in the work packages of many rural development NGOs across the rice-growing regions of Asia and some areas in Africa and Central America (Berkhout and Glover 2015). SRI was introduced in several villages located in the Himalaya foothills of Uttarakhand by the Mount Valley Development Association (MVDA), a regional NGO.

The MVDA worked with the farmers in Phalenda through what they call self-help groups, consisting of a number of households who collaborate in applying the introduced material inputs and instructions. The set of instruction that SRI comprised of concerns the handling of seedbeds, the small plots where seedlings are grown, the water management of the fields, the planting pattern, weed control and fertiliser application. The key task we focus on is to transplant very young seedlings, of about 8-15 days old, in a grid pattern specified of 25 by 25 centimetres. The instructions for the seedbed are to make sure the young seedlings can be taken out without damage. The changed water management prevents the young seedlings being washed away and, later on in the growing season, allows mechanical weeding and soil aeration to have a 
positive effect on the crop. The material inputs introduced by the MVDA are a rake-like device that is used to mark out the grid pattern, and mechanical rotary weeders to be pushed through the fields. The instructions also include application of organic manure, typically composted mixtures of animal manure and crop residues.
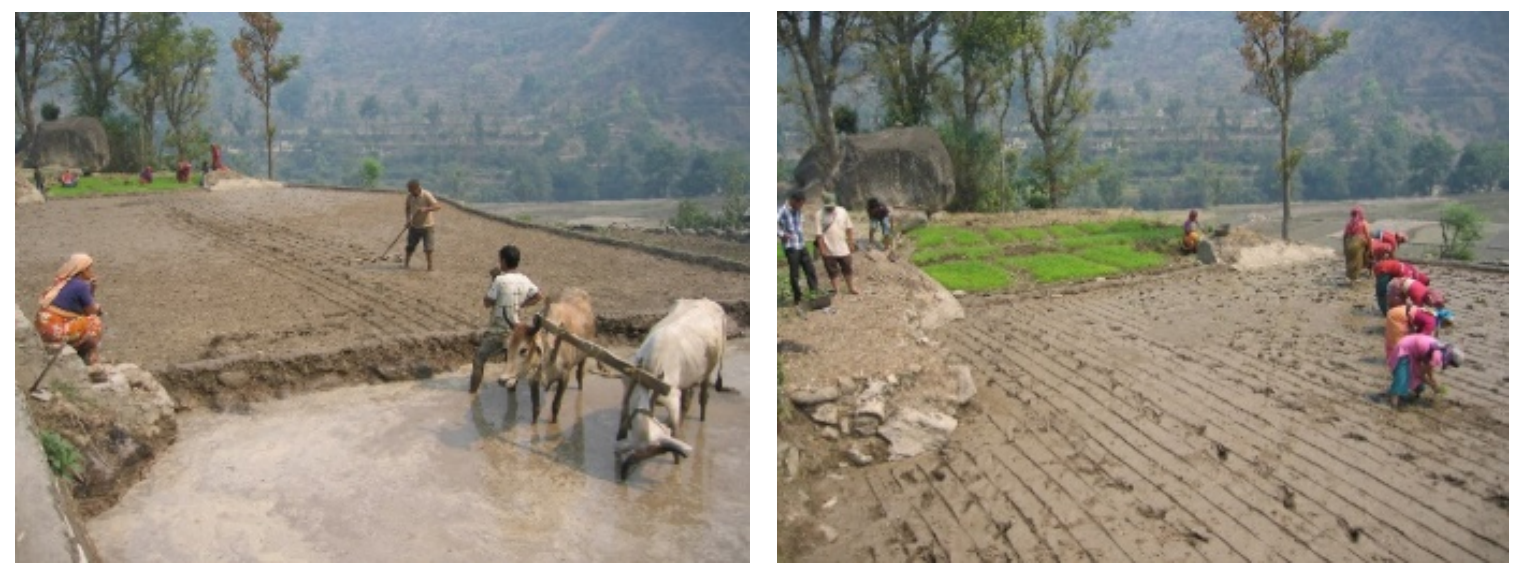

Figure 2: Rice growing according to the System of Rice Intensification (SRI) method in Phalenda, Uttarakhand, India.

The group transplanting the rice is called a padiyal. A padiyal is mostly composed by women of two or three households having their fields close to each other as few farm households have enough members to arrange all the work themselves. The periods of transplanting coincides with a school holiday period, allowing kids to participate. Family members from outside the village also come over to assist in the transplanting. A padiyal typically transplants a number of fields sequentially and group composition may change as they progress along the ready-made fields. Transplanting requires a watered, ploughed and levelled field. Few farmers own bullocks, so a team of bullocks typically ploughs many different fields. Transplanting is thus part of a wider taskscape and operational chain at the start of the season.

The new instructions for water management and marking out the grid pattern, part of the introduction of SRI, required a rearrangement of the sequential field preparation and transplanting tasks. For ploughing, a preferred water table of several centimetres facilitates the breaking of the soil and levelling. However, for the marking to be visible on the soil and to avoid the young seedlings being washed away, the fields needed to be drained after ploughing. This takes a day or two, and for some fields can last up to three days. Commonly, farmers cut out an opening on a bund to allow the water to flow out. As fields are connected, the drainage of one field is the irrigation for the next, lower field. Draining a field also implied watching the bunds and avoiding water from higher fields from flowing or leaking in. Also, rains could easily spoil a careful drainage plan. For these reasons, the timing of notifying the women to start transplanting was disconnected from the moment of ploughing. Occasionally women initially told to come to form a padiyal were sent home or to other places because fields were not sufficiently drained.

The marking was done by the contact person of the MVDA, called a Village Resource Person, usually the village head or another leading farmer. In Phalenda, this person marked over 70 of the 95 plots where SRI was applied. A device with six bent iron blades on a T-shaped handle was dragged through the muddy field, creating six parallel lines. This was repeated until the entire field was marked out and then the same operation was done once more at a ninety degree angle to create the grid pattern. Depending on the size of the field, this took from several minutes up to an hour. The women then entered the field to insert the seedlings at the points where the lines crossed. Usually two or three older women were busy uprooting the rice sprouts from the seedbed, putting them in baskets to be carried to the fields where transplanting 
took place. Although the lead farmer was in charge of marking, the women had to indicate when they were ready to transplant, creating an on-demand work schedule for him to serve the different padiyals. To speed up the work, sometimes only half of the marking was done, creating a line pattern instead of the required grid pattern.

The extra time it took to do grid marking was not the only reason for this. The women considered the transplanting on specific spots, where the lines crossed, too demanding. It required close attention to coordinate where to put the seedling. Also, stepping in the muddy field to fetch a new bunch of seedlings or changing lines could easily wipe out the cross points. Following marked lines was more convenient as locating the seedlings on the lines meant women could progress through the field next to each other at a regular pace. Every now and then the decision to do line marking or grid marking was made in a brief discussion between the padiyal woman and the Village Resource Person. Another reason given for this was that it facilitated weeding. The rotary weeder used for this was pushed through the lanes created by the planting pattern. Line planting required only one go with the weeder, but grid planting doubled the work. On one occasion we observed, this discussion took place in the presence of two members of MVDA field staff. When they heard that the women preferred line transplanting, they intervened and told them to do grid marking. The women followed this instruction, but overall line marking dominated over grid marking.

The change of the transplanting performance, brought about by marking the fields, affected the activity more substantially. The marking, line or grid, required a whole new way of moving through fields. In fields where SRI was not applied, women typically started in one corner of the field, inserting rice seedlings in the mud as far as the arm could reach, then stepping back and filling the next space in reach. In this way, the field was filled in semi-circular patches, gradually moving backwards across the field without stepping on the planted seedlings. In the SRI trainings, the women were told to move forward instead of backwards. Every woman was supposed to cover three to six lines, depending on their preferred reach. By moving forward, they could look ahead to avoid stepping on the crossing points. That also prevented them from stepping on the seedlings behind them. Moving across the field in this way worked for a line or a grid pattern. Women typically all started at the same moment, dividing up the number of lines they would cover and then move forward. Some teams worked at a very similar pace, moving to the next set of planting lines together. More commonly, some women moved faster and each took up a new set of lines when reaching the end of the field.

The new work pattern increased the flexibility of the number of women in a padiyal. The extra waiting time due to the drainage and marking of the fields resulted in an overall increase in the size of the transplanting teams. It was quite common to see transplanting starting with three or four women, increasing up to eight or ten women working in the same field, and concluding when women who had finished gradually moved out. Typically older women would stop somewhat earlier, not necessarily quitting the work entirely but moving to lighter tasks by joining the uprooting of seedlings or transport of seedlings. Young children also would transplant one or two lines, move up and down with the baskets of seedlings or fetching water for the others. The MVDA gradually accepted that they could not control these dynamics. They became less strict in prescribing grid transplanting and reformulated the instructions to recommend marking the fields 'at least in one direction.'

\section{Discussion and conclusion}

The two cases presented, independent as they are, show a very similar pattern of rearrangements made to tasks and group formation. Proposed changes to agricultural production, designed in settings remote from the context of application, reach a particular task environment as a set of moral and material incentives for groups to rearrange themselves in response to the rearrangement of tasks. The reordering of tasks thus reorders the group. In both examples, the group reordering was based on a predefined social organization. In the case of the spraying team, the group was defined by the cooperative and based on the set goal of applying spraying instructions. The group hardly ever reached the preferred number of twelve sprayers, as a combined effect of task performance and the connection with the wider taskscape of palm oil production. In the SRI example, the predefined group was based on the existing practice of rice farming. 
Although some women did not want to use the new way of transplanting in their field, the main change in the group composition was based on a change in timing of transplanting, as a result of the required marking and drying of the fields.

The focus on the interaction between group formation, task, and the wider setting provides a more profound understanding of the notion of performance. The examples suggest a useful distinction between the improvisational character of task preparation and improvisation in task accomplishment. The latter is the kind of improvisation that is generally attributed to the individual skill of the performer, responding to unexpected and other things happening along the way. This is the kind of improvisation that may be done primarily tacitly (Gore et al. 2012), for example oil palm sprayers running into problems with clogged-up nozzles and cleaning them, or the woman who transplants an extra row when another team member drops out. This is not to say that this is strictly individual capacity at work. Noting or observing the disturbance and responding to it is interactional in itself, and may be followed by complementary responses from team members. The improvisation linked to task preparation is about inspecting the stage, checking the instruments and looking ahead of the task. In both cases, this was visible most prominently when the team moved between fields. Team members inspect the situation and anticipate certain events, for example a long walk back with an empty sprayer. Improvisation in task preparation typically involves a deliberation about what to do best, for example a conversation with the lead farmer about line or grid marking of the field.

Task preparation and task accomplishment are ways in which a group relates, through a variety of connections, to more remote planners and designers. This connection is different from how other organizational forms, such as cooperatives or farmers' groups, relate to wider society. These latter types of organizations are defined in terms of the more generic interest of their members. The cooperative of the oil palm farmers in Sumatra played a role in introducing new farming practices, similar to the role of the selfhelp group in Phalenda. These are organizational forms created to facilitate interactions between members, organizations, and individuals. Cooperatives typically arrange scale benefits for their members by purchasing inputs and selling farm produce. This is a predominant and well-functioning role within fully commercialized production systems (Jelsma et al. 2017), like the one operated by the oil palm farmer. A cooperative, and similar member organizations, can have substantial group bargaining power vis-a-vis traders and other actors (Bonano et al. 2017). As the examples made clear, these groups also process information and, thereby, reconfigure newly introduced farm methods. What, then, can be concluded about these interactions and the bargaining position with respect to introduced technologies?

In his book about the early years of the Green Revolution, Nick Cullather shows that the newly created high-yielding rice variety IR- 8 conveyed a strong message about the powers of Western technology to Asian observers. During the Vietnam War the Americans set up an experimental farm growing IR-8 to showcase the affluence of food that US-style modernization had to offer. Technology, Cullather explains, is "an argument in the form of an object" (2010: 159). A similar point is made by Paul Richards about the ritual acts people engage in when important decisions have to be made. Extending the argument to a seed distribution project, Richards (2007: 22) asserts that the act of seed exchange between rural Sierra Leoneans in itself expressed the preferences for how that project should be implemented. Taken together, these two points make clear that the way groups implement introduced technologies contains an argument directed toward the organizations that propose new ways of working. Performing groups convey messages in their acts, and through their acts they exert a form of bargaining power. This power should not be underestimated as it can seriously thwart the projects and plans of developing agencies (Scott 1985). Moreover, in many places farmers have an option to escape from the ambitions of development agencies and develop their own form of production (Hazareesing and Maat 2016). In the two cases presented, the arguments expressed by the performing groups were not just about technical details and the pace of implementation but also about preferred ways of organising farm operations, labor conditions and payments. Moreover, the groups expressing these arguments were not the formal organizations, the cooperative of oil palm smallholders in Sumatra and the self-help group of Uttarakhand farmers, but groups organized around particular farm operations. The implementation of technology thus requires an understanding of what performing groups are, and what they do. 


\section{References}

Berkhout, E. and D. Glover. 2015. On-farm impact of the System of Rice Intensification (SRI): evidence and knowledge gaps. Agricultural Systems 132(1): 157-166.

Bonanno, A., C. Russo and L. Menapace. 2017. Market power and bargaining in agrifood markets: a review of emerging topics and tools. Agribusiness 34(1): 6-23.

Callon, M., P. Lascoumes and Y. Barthe. 2001. Acting in an uncertain world: an essay on technical democracy. Cambridge: MIT Press.

Collins, R. 2004. Interaction ritual chains. Princeton: Princeton University Press.

Crane, T.A. 2010. Of models and meanings: cultural resilience in social-ecological systems. Ecology and Society 15(4): 19.

Dant, T. 2007. The 'pragmatics' of material interaction. Journal of Consumer Culture 8(1): 11-33.

Douglas, M. and S. Ney. 1998. Missing persons: a critique of the social sciences. Berkeley and Los Angeles: University of California Press.

Durkheim, É. 1995 [1912]. Elementary forms of religious life. Tran. K. Fields. New York: Free Press.

Flachs, A. and P. Richards. 2018. Playing development roles: the political ecology of performance in agricultural development. Journal of Political Ecology 25: 638-646.

Flor, R.J., C. Leeuwis, H. Maat and M. Gummert. 2016. Rice postharvest learning alliance in Cambodia: comparison of assumptions and implementation of a network approach. Journal of Development Effectiveness 8(4): 489-507.

Gibson, J.J. 1979. The ecological approach to visual perception. Boston: Houghton Mifflin.

Glover, D. 2011. Science, practice and the System of Rice Intensification in Indian agriculture. Food Policy 36(6): 749-755.

Glover, D., J-P. Venot and H. Maat. 2017. On the movement of agricultural technologies: packaging, unpacking and situated reconfiguration. In Sumberg, J. (ed.). Agronomy for development; the politics of knowledge in agricultural research. London: Routledge. Pp. 14-30.

Gore, G., G. Rix-Lievre, O. Wathelet and A. Cazemajou. 2012. Eliciting the tacit: interviewing to understand bodily experience. In Skinner, J. (ed.) The interview: an ethnographic approach. London: Berg. Pp. 124-142.

Harrington E.B. and G.A. Fine. 2006. Where the action is: small groups and recent developments in sociological theory. Small Groups Research 37(1): 4-19.

Hazareesingh, S. and H. Maat 2016. Local subversions of colonial cultures: commodities and anticommodities in global history. Basingstoke: Palgrave Macmillan.

Hoffmann, V. 2007. Five editions (1962-2003) of Everett Rogers's diffusion of innovations. Book Review. The Journal of Agricultural Education and Extension 13(2): 147-158.

Ingold, T. 1993. The temporality of the landscape. World Archaeology 25(2): 152-174.

Isubikalu, P. 2007. Stepping-stones to improve upon functioning of participatory agricultural extension programmes: farmer field schools in Uganda. Ph.D. dissertation. Wageningen: Wageningen University.

Jelsma, I., M. Slingerland, K.E. Giller and J. Bijman. 2017. Collective action in a smallholder oil palm production system in Indonesia: the key to sustainable and inclusive smallholder palm oil? Journal of Rural Studies 54(1): 198-210.

Lansing, J.S. 1987. Balinese "water temples" and the management of irrigation. American Anthropologist 89(2): 326-341.

Latour, B. 1992. Where are the missing masses? The sociology of a few mundane artifacts. In W. Bijker and J. Law (eds.), Shaping technology/building society: studies in sociotechnical change. Cambridge, MA: The MIT Press, pp. 225-258. 
Latour, B. 2005. Reassembling the social: an introduction to actor-network theory. Oxford: Oxford University Press.

Lemonnier P. 1992. Elements for an anthropology of technology. Anthropological papers, No.88. Ann Arbor: Museum of Anthropology, University of Michigan.

Lisnawati, L. 2017. Group dynamics: the relation between working system, membership change \& leadership, and group performances in the realization of RSPO P\&C in smallholder plantations. M.Sc. Thesis. Wageningen: Wageningen University.

Macnaghten, P. and J. Urry. 2000. Bodies in the woods. Body and Society 6(3): 169-185.

McFeat, T. 1974. Small-group cultures. New York: Pergamon Press.

Pfaffenberger, B. 1992. Social anthropology of technology. Annual Review of Anthropology 21(1): 491516.

Porter T.M., 1995. Trust in numbers: the pursuit of objectivity in science and public life. Princeton: Princeton University Press.

Richards, P. 1989. Agriculture as a performance. In R. Chambers, A. Pacey and L.A. Thrupp (eds.). Farmer first: farmer innovation and agricultural research. Rugby: Intermediate Technology Publications. Pp. 39-42.

Richards, P. 1993. Cultivation: knowledge or performance? In M. Hobart (ed.). An anthropological critique of development: the growth of ignorance. London: Routledge. Pp. 61-78.

Richards, P. 2004. Private versus public? Agenda-setting in international agrotechnologies. In Jansen, K. and S. Vellema. (eds.). Agribusiness and society: corporate responses to environmentalism, market opportunities and public regulation. London: Zed Books. Pp. 261-287.

Richards, P. 2005. West-African warscapes: war as smoke and mirrors: Sierra Leone 1991-2, 1994-5, 19956. Anthropological Quarterly 78(2): 377-402.

Richards, P. 2007. How does participation work? Deliberation and performance in African food security. IDS Bulletin 38(5): 21-35.

Ruysschaert, D. and D. Salles 2014. Towards global voluntary standards: questioning the effectiveness in attaining conservation goals. The case of the roundtable on sustainable palm oil (RSPO). Ecological Economics 107: 438-446.

Schlanger, N. 2006. Marcel Mauss: techniques, technology and civilisation. Oxford: Berghahn.

Scott, J.C. 1985. Weapons of the weak; everyday forms of peasant resistance. New Haven: Yale University Press.

Sen, D. 2016. How smallholder farmers in Uttarakhand reworked the system of rice intensification: innovations from sociotechnical interactions in fields and villages. Ph.D. dissertation. Wageningen: Wageningen University.

Sen D., H. Maat, D. Glover and C. Shambu Prasad. 2017. The introduction of SRI in Uttarakhand, India: technopolitical mythologies and sociotechnical flexibility. Anthropologie et Développement 46(1) \& 47(1): 101-127.

Sigaut, F. 2002. Technology. In Ingold, T. (ed.) Companion encyclopedia of anthropology: humanity, culture and social life. London: Routledge. Pp. 420-459.

Stone, G.D. 2007. Agricultural deskilling and the spread of genetically modified cotton in India. Current Anthropology 48(1): 67-103.

Stone, G.D. 2011. Field versus farm in Warangal: Bt cotton, higher yields, and larger questions. World Development 39(3): 387-398.

Stone, G.D. 2016. Towards a general theory of agricultural knowledge production: environmental, social, and didactic learning. Culture, Agriculture, Food and Environment 38(1): 5-17.

Stoop W., N. Uphoff and A. Kassam. 2002. A review of agricultural research issues raised by the system of rice intensification (SRI) from Madagascar: opportunities for improving farming systems for resource-poor farmers. Agricultural Systems 71(1): 249-274. 
Suchman, L.A. 1987. Plans and situated actions: the problem of human-machine communication. Cambridge: Cambridge University Press.

Uphoff, N. 1999. Agroecological implications of the system of rice intensification (SRI) in Madagascar. Environment, Development and Sustainability 1(3-4): 297-313.

Uphoff, N. 2003. Higher yields with fewer external inputs? The system of rice intensification and potential contributions to agricultural sustainability. International Journal of Agricultural Sustainability 1: 38-50.

Winner, L. 1995. Citizen virtues in a technological order. In Feenberg, A. and A. Hannay (eds.). Technology and the politics of knowledge. Bloomington: Indiana University Press. Pp. 65-84. 